\title{
Pengaruh Fenantren terhadap Aktivitas Enzim Katabolik Pseudomonas Putida TI (8)
}

\author{
Influence of Phenanthrene on Activity of Pseudomonas Putida TI (8) Catabolic Enzyme
}

\author{
Meilisa Rusdiana Surya Efendi ${ }^{*}$ ), Sri Sumarsih ${ }^{2)}$, Novia Fajarwati ${ }^{1)}$ \\ ${ }^{1)}$ Universitas Bojonegoro, Prodi Kimia, Indonesia \\ ${ }^{2)}$ Universitas Airlangga, Prodi Kimia, Indonesia \\ *email: meilisarusdiana11@gmail.com
}

Received: 02/11/20; Revised: 25/12/20; Accepted: 25/12/20

\begin{abstract}
Abstrak
Penelitian ini bertujuan untuk menguji pengaruh fenantren terhadap aktivitas enzim katabolik pada Pseudomonas putida TI (8). Isolat ditumbuhkan pada media Air Mineral Sintetis (AMS) dengan penambahan $1 \%$ fenantren. Enzim katabolik diuji aktivitasnya terhadap fenantren. Uji aktivitas enzim ditentukan berdasarkan penurunan absorbansi NADH pada panjang gelombang $340 \mathrm{~nm}$. Satu unit aktivitas enzim dinyatakan sebagai jumlah enzim yang membutuhkan $1 \mu$ mol NADH untuk mengoksidasi substrat. Hasil penelitian menunjukkan bahwa isolat dapat tumbuh menggunakan fenantren hingga 10 hari inkubasi. Aktivitas enzim katabolik tertinggi terhadap fenantren pada inkubasi hari ke 8 sebesar 5,391 U/mL. Penambahan $1 \%$ hidrokarbon poliaromatik dapat meningkatkan aktivitas enzim sebesar 10 kali, hal ini menunjukkan bahwa enzim katabolik pada Pseudomonas putida TI (8) merupakan enzim induktif.
\end{abstract}

Kata kunci: bakteri hidrokarbonoklastik; enzim katabolik; fenantren; Pseudomonas putida T1 (8)

\begin{abstract}
This research aims to study the influence of phenanthrene on activity of catabolic enzyme from hydrocarbonoclastic bacteria Pseudomonas putida TI (8). Isolates were grown on a synthetic mineral water media and $1 \%$ phenanthrene. Catabolic enzymes was tested its activity toward phenanthrene. The value of enzyme activity is determined based on a decrease in NADH absorbance at a wavelength of $340 \mathrm{~nm}$. One unit of enzyme activity is expressed as the amount of enzymes which requires 1 umole of NADH to oxidize substrates. The research showed that the isolates could be grown using phenanthrene for up to 10 days of incubation. Catabolic enzyme activity is the highest of phenanthrene were achieved at 8 days incubation with $5.391 \mathrm{U} / \mathrm{mL}$. The addition of substrate can increase the enzyme activity up to 10-fold, indicating that the catabolic enzyme from Pseudomonas putida TI (8) is an inductive enzymes.
\end{abstract}

Keywords: catabolic enzyme; hydrocarbonoclastic bacteria; phenanthrene; Pseudomonas putida T1 (8)

\section{PENDAHULUAN}

Fenantren merupakan hidrokarbon yang tergolong dalam polycyclic aromatic hydrocarbons (PAH). Golongan ini mewakili sekelompok polutan lingkungan yang banyak mengkontaminasi tanah dan sedimen, serta menjadi perhatian akibat efek karsinogenik atau mutagenik (Zam, 2011).
Keberadaan PAH sebagai polutan sering dihasilkan dari kegiatan eksplorasi dan industri pengilangan minyak bumi. Pada pengilangan minyak bumi terdapat produk samping berupa limbah lumpur minyak bumi (oil sludge) (Chelyadyn $d k k ., 2020$ ).

Upaya pengolahan limbah oil sludge dapat diatasi dengan metode biologi, fisika 
atau kimia. Metode secara biologi merupakan metode yang efektif dari segi biaya dan ramah lingkungan. Metode ini memanfaatkan mahluk hidup khususnya mikroorganisme sebagai upaya pembersihan oil sludge (Bharali dkk., 2018). Pengolahan secara fisika dan kimia membutuhkan biaya yang mahal dan dapat menimbulkan pencemar baru.

Proses penguraian oleh aktivitas mikroba, yang mengakibatkan transformasi struktur suatu senyawa sehingga terjadi perubahan integritas molekuler atau menguraikan senyawa yang berbahaya menjadi tidak berbahaya bagi lingkungan disebut dengan biodegradasi (Seo, 2009). Dalam proses biodegradasi terjadi konversi dari bahan-bahan kimia yang komplek menjadi produk-produk yang termineralisasi seperti air $\left(\mathrm{H}_{2} \mathrm{O}\right)$ dan karbondioksida $\left(\mathrm{CO}_{2}\right)$ (Nzila, 2013).

Mikroorganisme yang digunakan dalam proses degradasi hidrokarbon poliaromatik yaitu bakteri gram positif dan gram negatif seperti Aeromonas hydrophila, Acinetobacter faecalis tipe II, Actinobacillus sp, Pseudomonas putida, Pseudomonas cepacea, dan Pseudomonas pseudomallei (Kanaly \& Harayama, 2000). Secara alami mikroorganisme ini memiliki kemampuan untuk mentranspor, mengikat, mengemulsi dan mendegradasi hidrokarbon (Zam, 2011). $P$. putida TI (8) menghasilkan biosurfaktan seperti hasil penelitian Alami (2010), bahwa $P$. putida TI (8) memiliki produk biosurfaktan sebesar 9,8 g/L. P. putida TI (8) memiliki enzim katabolik yang dapat mempengaruhi kemampuan bakteri dalam mendegradasi hidrokarbon menjadi senyawa metabolit yang lebih sederhana. Enzim ini merupakan enzim kunci dalam degradasi hidrokarbon aromatik (Yani $d k k$., 2020). Adanya enzim menjadikan bakteri bisa mendegradasi polimer hidrokarbon menjadi senyawa yang tidak kompleks sehingga dapat dimanfaatkan sebagai sumber karbon dan energi oleh bakteri. Keberadaan enzim juga berhubungan dengan proses pengambilan substrat oleh bakteri (Olivera \& Luengo, 2019).

Beberapa enzim telah dikaitkan dengan biodegradasi hidrokarbon, khususnya PAH. Enzim dioksigenase adalah contoh enzim yang bekerja pada degradasi aerobik hidrokarbon aromatik. Enzim ini awalnya akan mengoksidasi PAH sehingga menghasilkan cis-dihidrodiol yang selanjutnya diubah menjadi senyawa hidroksi seperti katekol dan mengalami pembelahan posisi orto menghasilkan cis-cis asam mukonat dan mengalami pembelahan posisi meta menjadi 2-hidroksi mukonat semi aldehid, serta beberapa senyawa karboksilat (Grimm \& Harwood, 1997; Crawford \& Crawford, 1996; Seo, 2009).

Salah satu faktor yang berperan penting dalam degradasi adalah pertumbuhan dan kebutuhan nutrisi untuk menunjang aktivitas mikroorganisme pendegradasi. Berdasarkan studi literatur, $P$. putida TI (8) berpotensi mendegradasi senyawa PAH, tetapi penelitian tentang uji aktivitas enzim katabolik oleh $P$. putida TI (8) terhadap fenantren belum pernah dilakukan, sehingga tujuan penelitian ini adalah untuk mengethaui pengaruh fenantren tehadap aktivitas enzim katabolik pada $P$. putida TI (8). Dalam penelitian ini diamati pertumbuhan $P$. putida TI (8) dalam media yang mengandung fenantren dan uji aktivitas enzimnya terhadap substrat tersebut.

\section{METODE PENELITIAN}

Penelitian ini menggunakan bakteri Pseudomonas putida T1 (8) yang diisolasi dari Tanjung Perak Surabaya dan dilakukan 
penelitian di Laboratorium mikrobiologi Universitas Airlangga Surabaya.

\section{Alat dan Bahan}

Bahan-bahan yang digunakan dalam penelitian ini adalah P. Putida TI (8), media Nutrient Agar (NA), Nutrient Broth (NB), fenantren, NADH, yeast extract, AMS. Alatalat yang digunakan dalam penelitian ini adalah spektrofotometri UV-VIS, centrifuge, neraca analitik, pipet mikro, inkubator, autoclave, laminar air flow cabinet, dan shaker incubator.

\section{Peremajaan Bakteri}

Langkah-langkah penelitian ini adalah melakukan peremajaan $P$. putida TI (8) dalam media NA dan diinkubasi selama 24 jam pada suhu kamar. Pertumbuhan $P$. putida TI (8) diukur dalam $20 \mathrm{~mL}$ media garam mineral sintetis yang mengandung $1 \%$ fenantren dan diinkubasi dengan shaker 100 rpm pada suhu $30{ }^{\circ} \mathrm{C}$ selama 14 hari. Perlakuan kontrol diukur dalam $20 \mathrm{~mL}$ media garam mineral sintetis tanpa penambahan fenantren dan diinkubasi dengan kondisi yang sama sebagai acuan pertumbuhan bakteri. Pertumbuhan bakteri diamati dengan pengukuran turbiditas dari optical density (OD) pada $600 \mathrm{~nm}$ menggunakan spektrofotometer UV/Vis dengan interval 2 hari (Abbasian $d k k$., 2015). Pengukuran optical density (OD) didasarkan pada pemisahan cahaya dengan panjang gelombang $600 \mathrm{~nm}$. Panjang gelombang ini memiliki warna orange, pemilihan panjang gelombang $600 \mathrm{~nm}$ dikarenakan bahan organik lebih mudah menyerap cahaya, sehingga sel mikroorganisme dapat diperkirakan kuantitasnya dengan panjang gelombang ini (Sudarmadji, 1996).

\section{Analisis Biomassa Sel}

Sel dipanen dengan cara disentrifugasi pada kecepatan 5000 rpm. Supernatan dipisah untuk uji aktivitas enzim ekstraselular, pelet kemudian diresuspensikan dalam $1 \mathrm{~mL}$ buffer Tris- $\mathrm{HCl}$ $20 \mathrm{mM}$ pH 7,4. Pelet lalu disonikasi menggunakan ultrasonic disintegrator, dan disentrifuse selama 10 menit pada kecepatan $8000 \mathrm{rpm}$ pada suhu $4{ }^{\circ} \mathrm{C}$. Supernatan yang telah bebas sel digunakan untuk uji aktivitas enzim intraselular.

\section{Uji Aktivitas Enzim}

Supernatan yang telah bebas sel digunakan untuk uji aktivitas enzim fenantren dioksigenase. Campuran reaksi mengandung buffer Tris- $\mathrm{HCl} 20 \mathrm{mM}$; NADH 0,1 mM; dan $2 \mu \mathrm{L}$ larutan fenantren (1\% fenantren dalam $80 \%$ DMSO), dan 20 $\mu \mathrm{L}$ enzim sehingga volume total larutan uji adalah $200 \mu \mathrm{L}$. Reaksi dimulai dengan penambahan $2 \mu \mathrm{L}$ larutan substrat ke dalam campuran reaksi. Campuran kemudian dihomogenkan menggunakan vortex selama 3 detik dan diinkubasi selama 6 menit. Absorbansi campuran diukur menggunakan microplate reader pada panjang gelombang $340 \mathrm{~nm}$. Nilai absorbansi yang diperoleh selanjutnya digunakan untuk menentukan besarnya aktivitas enzim. Satu unit aktivitas enzim fenantren dioksigenase dinyatakan sebagai banyak nya enzim yang membutuhkan $1 \mu$ mol NADH untuk mengoksidasi substrat (Jauhari dkk., 2014; Mishra $d k k ., 2014$; Singh $d k k ., 2013$; Mishra \& Singh, 2012).

\section{Analisis Data Uji Aktivitas Enzim}

Satu unit aktivitas enzim dinyatakan sebagai banyaknya enzim yang membutuhkan $1 \mu$ mol NADH untuk mengoksidasi substrat per menit per $\mathrm{mL}$ enzim. Besarnya aktivitas enzim ditentukan 
dari nilai absorbansi yang di dapat setelah pengukuran campuran reaksi enzimatis menggunakan microplate reader dengan persamaan (1)

Aktivitas enzim $\left(\frac{U}{m L}\right)=\frac{\Delta A_{340} \times V_{e}}{A_{340} \times V_{s} \times 1 \times l} \ldots$

Dengan:

$\Delta \mathrm{A}_{340}$ : Selisih absorbansi NADH awal dan absorbansi tes

$\mathrm{A}_{340}$ : Absortivitas molar NADH, sebesar 6,22 mL $\mu \mathrm{mol}^{-1} \mathrm{~cm}^{-1}$

$\mathrm{V}_{\mathrm{e}} \quad$ : Volume enzim, sebesar $1 \mathrm{~mL}$

$\mathrm{V}_{\mathrm{s}} \quad$ : Volume sampel enzim, sebesar $0,01 \mathrm{~mL}$

$\mathrm{t} \quad$ : Waktu inkubasi, sebesar 5 menit

l : pathlength, sebesar $0,05 \mathrm{~cm}$

\section{HASIL DAN PEMBAHASAN}

Respon pertumbuhan atau optical density (OD) $P$. putida TI (8) yang ditumbuhkan dalam media air mineral sintetik (AMS) dengan penambahan substrat fenantren dan tanpa penambahan substrat fenantren disajikan pada Gambar 1. P. putida TI (8) dapat menggunakan $1 \%$ substrat hidrokarbon poliaromatik (fenantren) sebagai substrat pertumbuhannya.

P. putida TI (8) pada media AMS tanpa penambahan fenantren dan dengan penambahan substrat fenantren mengalami pertumbuhan sejak hari kedua tanpa didahului fase lag. Pada Gambar 1 terlihat bahwa ada perbedaan pola pertumbuhan $P$. putida TI (8) antara tanpa penambahan substrat hidrokarbon dan penambahan substrat hidrokarbon. Selain itu, biomassa sel tanpa penambahan substrat hidrokarbon lebih sedikit dibandingkan dengan biomassa sel pada penambahan substrat hidrokarbon yang disajikan pada Gambar 2. Hal ini menunjukkan adanya adaptasi dan penggunaan substrat oleh $P$. putida TI (8) untuk tumbuh.

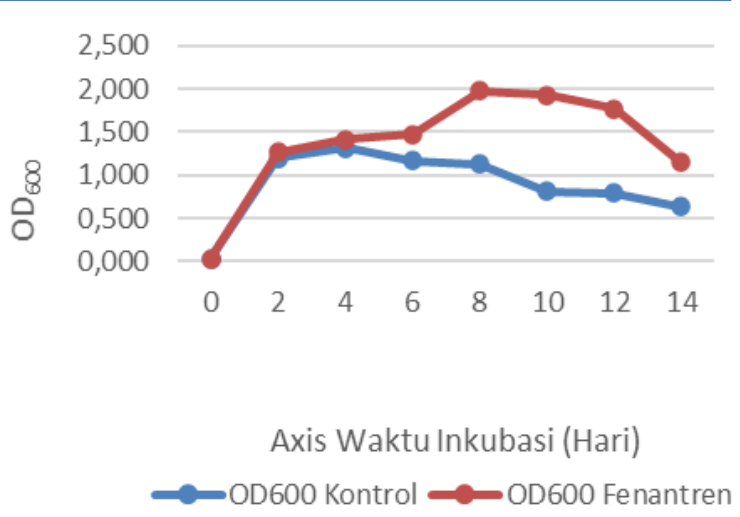

Gambar 1. Kurva Pertumbuhan P. putida TI (8)

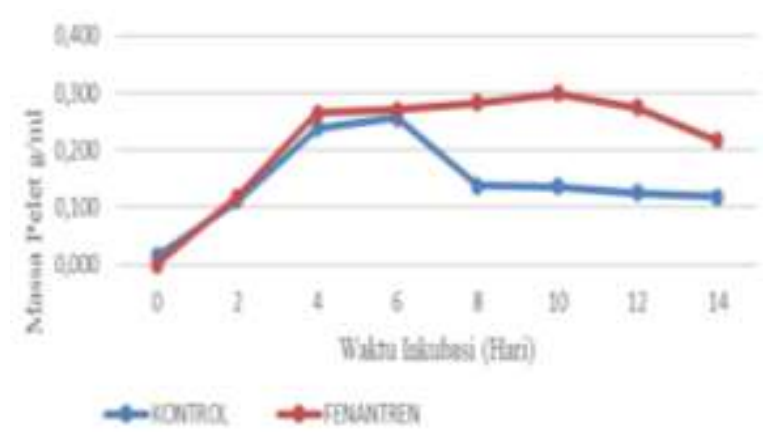

Gambar 2. Kurva Biomassa Sel P. putida TI (8)

$P$. putida TI (8) dapat tumbuh dan beradaptasi dengan adanya fenantren $\left(\mathrm{C}_{14} \mathrm{H}_{10}\right)$ sebagai sumber energi dan sumber karbon. Fase pertumbuhan $P$. putida TI (8) dengan adanya fenantren dapat meningkatkan nilai OD dan massa sel dengan bertambahnya waktu inkubasi dibandingkan dengan tanpa penambahan fenantren. Bakteri dapat mengalami fase stasioner saat sel terhambat karena massa sel mengalami penurunan seiring dengan meningkatnya waktu inkubasi dan sel mengalami toksisitas terhadap fenantren serta berkurangnya jumlah oksigen dalam sel (Pelczar, 1986). Selain itu, fase stasioner terjadi karena zat makanan yang diperlukan bakteri berkurang dan hasil ekskresi bakteri dapat tertimbun dalam medium, sehingga mengganggu perkembangbiakan dan pertumbuhan bakteri selanjutnya. Kontak langsung antara $P$. putida TI (8) dengan fenantren dapat mempengaruhi bakteri untuk melepaskan enzim yang dibutuhkan oleh bakteri dalam 
biodegradasi yaitu untuk mengkatalisis reaksi oksidasi pada hidrokarbon (Tuleva $d k k ., 2005$; Alrumman $d k k ., 2015$ ).

Produksi enzim dioksigenase dilakukan dengan menumbuhkan $P$. putida TI (8) pada media dengan penambahan fenantren dan media tanpa adanya fenantren dengan waktu kultivasi selama 14 hari. Uji aktivitas enzim dioksigenase dari Pseudomonas putida TI (8) dilakukan dengan menggunakan ELISA. ELISA adalah salah satu uji serologis yang dapat digunakan untuk mengukur antigen/antibodi. Prinsip utama teknik ELISA adalah penggunaan indikator enzim untuk reaksi imunologi (Wulandari $d k k ., 2019$ ).

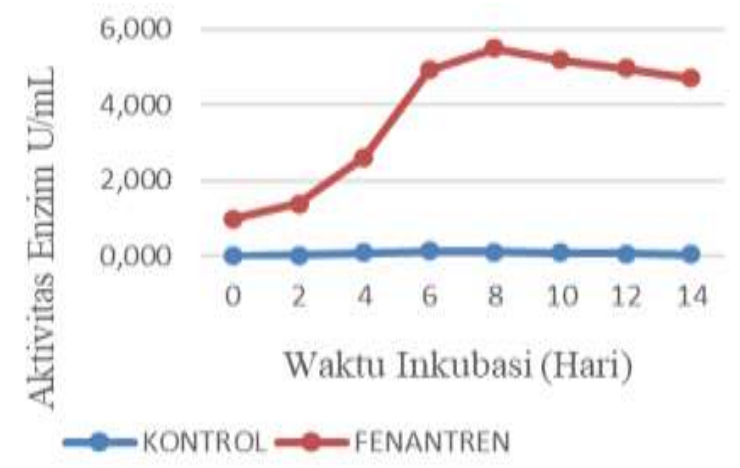

Gambar 3. Aktivitas enzim P. putida TI (8) yang ditumbuhkan pada Fenantren

Dari Gambar 3 bisa disimpulkan bahwa fenantren dioksigenase dengan penambahan fenantren mempunyai aktivitas tertinggi saat inkubasi pada hari ke-8 sebesar $5,391 \mathrm{U} / \mathrm{mL}$. Sedangkan aktivitas terendah pada waktu inkubasi hari ke-0, karena belum adanya penggunaan fenantren oleh $P$. putida TI (8) sebagai sumber karbon. Pada hari ke8 inkubasi terjadi fluktuasi aktivitas enzim yang tinggi karena laju pertumbuhan sel bakteri mencapai titik maksimal dan terjadi pertumbuhan secara logaritmik atau eksponensial.

Dari hasil penelitian, maka dapat disimpulkan bahwa $P$. putida TI (8) memiliki aktivitas enzim fenantren dioksigenase. Enzim ini dibutuhkan oleh $P$. putida TI (8) sebagai katalis reaksi oksidasi hidrokarbon untuk mendegradasi fenantren (Kanaly \& Harayama, 2000). Adanya enzim ini menjadikan bakteri mampu merubah hidrokarbon menjadi senyawa lebih kecil sehingga dapat dijadikan sebagai sumber makanan oleh bakteri (Devi \& Jha, 2020). Bakteri ini dapat merubah dan memecah fenantren menjadi senyawa golongan catechol yang digunakan oleh bakteri untuk proses metabolisme asam sitrat (Hamzah $d k k ., 2011)$. P. putida TI (8) menggunakan fenantren sebagai satu-satunya sumber substrat dan energi sehingga termasuk degradasi asimilatif (Lawal, 2017; Amezcua-Allieri $d k k .$, 2012).

Enzim pada $P$. putida TI (8) berperan dalam proses katabolisme hidrokarbon tahap pertama. Katabolisme adalah reaksi pemecahan senyawa kompleks menjadi senyawa-senyawa yang lebih sederhana dengan menghasilkan energi yang dapat digunakan oleh bakteri untuk melakukan aktivitasnya. Tahap pertama katabolisme aromatik oleh $P$. putida TI (8) masingmasing dikode oleh enzim aromatik dioksigenase. Enzim dioksigenase yang dihasilkan oleh bakteri $P$. putida TI (8) mampu membuka ikatan karbon pada cincin aromatik (fenantren) dan menghasilkan cisdihidrodiol. Senyawa ini kemudian didehidrogenasi untuk membentuk dihidroksi fenantren yang merupakan substrat untuk enzim melakukan metabolisme. Senyawa tersebut selanjutnya didegradasi menjadi senyawa yang dapat masuk ke dalam siklus krebs, yaitu asam suksinat dan asetil CoA. Asetil CoA akan memasuki siklus asam trikarboksilat di dalam sel bakteri untuk menghasilkan $\mathrm{CO}_{2}$ dan $\mathrm{H}_{2} \mathrm{O}$ serta energi untuk pertumbuhan bakteri $P$. putida TI (8). Fenantren 
dioksigenase merupakan enzim kunci dalam degradasi hidrokarbon aromatik (Demaneche $d k k .$, 2004).

\section{KESIMPULAN DAN SARAN}

Hasil penelitian menunjukkan aktivitas enzim katabolik tertinggi terhadap fenantren pada inkubasi hari ke 8 sebesar 5,391 U/mL. Penambahan $1 \%$ hidrokarbon poliaromatik dapat meningkatkan aktivitas enzim sebesar 10 kali. Saran untuk penelitian selanjutnya yaitu perlu dilakukan deteksi gen penyandi enzim fenantren dioksigenase dari Pseudomonas putida TI (8).

\section{DAFTAR PUSTAKA}

Abbasian, F., Lockington, R., Mallavarapu, M., \& Naidu, R. (2015). A Comprehensive Review of Aliphatic Hydrocarbon Biodegradation by Bacteria. Journal of Biochemistry and Biotechnology, 176(3), 670-699, doi: 10.1007/s12010-015-1603-5

Alami, N. H. (2010). Efektivitas Biosurfaktan Pseudomonas Putida T1(8) Dalam Bioremediasi Tanah Tercemar Minyak Mentah. Tesis: Universitas Airlangga. http://repository.unair.ac.id/38351/

Alrumman, S. A., Standing, D. B., \& Paton, G. I. (2015). Effect of Hydrocarbon Contamination on Soil Microbial Community and Enzyme Activity. Journal of King Saud UniversityScience, 27(1), 31-41, doi: 10.1016/j.jksus.2014.10.001

Amezcua-Allieri, M. A., Ávila-Chávez, M. A., Trejo, A., \& Melendez-Estrada, J. (2012). Removal of Polycyclic Aromatic Hydrocarbons from Soil: A Comparison Between Bioremoval and Supercritical Fluids Extraction. Chemosphere, 86(10), 985-993, doi: 10.1016/j.chemosphere.2011.11. 032

Bharali, P., Singh, S. P, Bashir, Y., Dutta, N., Konwar, B. K, \& Singh, C. B. (2018). Characterization and Assessment of
Biosurfactant Producing Indigenous Hydrocarbonoclastic Bacteria: Potential Application in Bioremediation. Nova Biotechnologica et Chimica, 17(2), 103-114, doi: 10.2478/nbec-20180011

Chelyadyn, V. L., Bogoslavets, M. M., Chelyadyn, L. I., Poznyak, O. R., \& Novosad, P. V. (2020). Sludge of Oil Refining Units and Their Processing. Journal of Ecological Engineering, 21(7), 169-177, doi: $10.12911 / 22998993 / 125556$

Crawford, R. L., \& Crawford, D. L. (1996). Bioremediation: Principls and Applications. Cambridge, UK: Cambridge University Press.

Demaneche, S., Meyer C., Micoud, J., Louwagie, M., Willison, J. C., \& Jouanneau, Y. (2004). Identification and Functional Analysis of Two Aromatic-Ring-Hydroxylating Dioxygenases from a Sphingomonas Strain that Degrades Various Polycyclic Aromatic Hydrocarbons. Applied and Environmental Microbiology, 70(11), 6714-6725, doi: 10.1128/AEM.70.11.6714-6725.2004

Devi, S. P \& Jha, D. K. (2020). Screening of Bacteria Isolated from Refinery Sludge of Assam for Hydrocarbonoclastic Activities. Journal of Pure and Applied Microbiology, 14(2), 14531465, doi: 10.22207/JPAM.14.2.43

Grimm, A. C., \& Harwood, C. S. (1997). Chemotaxis of Pseudomonas spp to the Polyaromatic Hydrocarbon Naphthalene, Applied and Environmental Microbiology, 63(10), 4111-4115, doi: 10.1128/AEM.63.10.41114115.1997

Hamzah, A., Tavakoli, A., \& Rabu, A. (2011). Detection of Toluene Degradation in Bacteria Isolated from Oil Contaminated Soil. Sains Malaysiana, 40(11), 1231-1235, http://journalarticle.ukm.my/2932/

Jauhari, N., Mishra, S., Kumari, B., \& Singh, S. N. (2014). Bacteria Mediated 
Aerobic Degradation of Hexacosane in vitro Conditions. Bioresource Technology, $\quad 170, \quad 62-68$, doi: 10.1016/j.biortech.2014.07.091

Kanaly, R. A, \& Harayama, S. (2000). Bioderadation of High-MolecularWeight Polycyclic Aromatic Hydrocarbons by Bacteria. Journal of Bacteriology, 182(8), 2059-2067, doi: 10.1128/JB.182.8.2059-2067.2000

Lawal, A. T. (2017). Polycyclic Aromatic Hydrocarbon. A review, Cogent Environmental Science, 3, 1-89, doi: 10.1080/23311843.2017.1339841

Mishra, S. \& Singh, S. N. (2012). Microbial Degradation of n-Hexadecane in Mineral Salt Medium as Mediated by Degradative Enzymes. Bioresource Technology 111, 148-154, doi: 10.1016/j.biortech.2012.02.049

Mishra, S., Singh, S. N., \& Pande, V. (2014). Bacteria Induced Degradation of Fluoranthene in Minimal Salt Medium Mediated by Catabolic Enzymes in vitro Condition. Bioresource Technology, 164, 299-308, doi: 10.1016/j.biortech.2014.04.076

Nzila, A. (2013). Update on the Cometabolism of Organic Pollutants by Bacteria. Environmental Pollution, 178 , 474-482. doi: 10.1016/j.envpol.2013.03.042

Olivera, E. R, \& Luengo, J. M. (2019). Steroids as environmental compounds recalcitrant to degradation: Genetic mechanisms of bacterial biodegradation pathways. Genes, 10(7), 512, doi: $10.3390 /$ genes 10070512

Pelczar, J. M. (1986). Dasar-Dasar Mikrobiologi. Jakarta: Universitas Indonesia.

Seo, J-S., Keum, Y-S., \& Li, Q. X. (2009). Bacterial Degradation of Aromatic Compounds. Environmental Research and Public Health, 6(1), 278-309, doi: 10.3390/ijerph6010278
Singh, S. N., Kumari, B., Upadhyay, S. K., Mishra, S., \& Kumar, D. (2013). Bacterial Degradation of Pyrene in Minimal Salt Medium Mediated by Catechol Dioxygenases: Enzyme Purification and Molecular Size Determination. Bioresource Technology 133, 293-300, doi: 10.1016/j.biortech.2013.01.068

Sudarmadji, S. (1996). Teknik Analisa Biokimiawi. Yogyakarta: Liberty.

Tuleva, B., Christova, N., Jordanov, B., Nikolova-Damyanova, B., \& Petrov, P. (2005). Naphthalene Degradation and Biosurfactant Activity by Bacillus Cereus 28BN. Zeitschrift fur Naturforschung C, 60(7), 577-582, doi: 10.1515/znc-2005-7-811

Wulandari, Y. T., Susanti, R., \& Bintari, S. H. (2019). Analisis Perkembangan Titer Antibodi Hasil Vaksinasi Infectious Bronchitis pada Ayam Petelur Strain Hisex Brown. Life Science, 8(1), 2533, doi: 10.15294/lifesci.v8i1.29987

Yani, M., Charlena,C., Mas'ud Z, A., Anas, I., Setiadi, Y., Syakti, A. D. (2020). Isolation, Selection and Identification of Polyaromatic Hydrocarbons (PAHs) Degrading Bacteria from Heavy Oil Waste (HOW)-Contaminated Soil. HAYATI Journal of Biosciences, 27(2), 142-153, https://journal.ipb.ac.id/index.php/hayati/article/view/31498

Zam, S. I. (2011). Bioremediasi Tanah yang Tercemar Limbah Pengilangan Minyak Bumi secara In Vitro pada Konsentrasi pH Berbeda. Jurnal Agroteknologi, 1(2), 1-8, http://ejournal.uinsuska.ac.id/index.php/agroteknologi/a rticle/view/50 